\title{
Serum biomarker profiles of interleukin-6, tumor necrosis factor- alpha, matrix-metalloproteinase-2, and vascular endothelial growth factor in endometriosis staging
}

\author{
Wachyu Hadisaputra, Sandhy Prayudhana \\ Department of Obstetrics and Gynecology, Faculty of Medicine, Universitas Indonesia, Cipto Mangunkusumo Hospital, Jakarta, \\ Indonesia
}

\begin{abstract}
Abstrak
Latar belakang: Penelitian ini bertujuan untuk membandingkan kadar serum penanda biologis: interleukin-6 (IL-6), tumor necrosis factor-alpha (TNF- $\alpha$ ), matrik-metaloproteinase-2 (MMP-2), dan vascular endothelial growth factor (VEGF) pada endometriosis stadium I-II dan stadium III-IV.

Metode: Penelitian ini adalah penelitian potong lintang pada empat puluh pasien endometriosis yang didiagnosis berdasarkan laparoskopi. Sampel serum diambil sebelum operasi, pemeriksaan penanda biologis dilakukan pada akhir penelitian dengan metode ELISA. Rerata kadar serum dibandingkan dengan menggunakan uji t tidak berpasangan. Variabel yang memiliki perbedaan rerata bermakna diuji dengan pemeriksaan ROC dan ditentukan titik potong optimal.

Hasil: Kadar serum IL-6, TNF- $\alpha$, dan MMP-2 tidak berbeda bermakna pada pasien endometriosis stadium I-II dan stadium III-IV dengan hasil rerata 1,58 $\pm 0,78 \mathrm{vs} 1,55 \pm 0,98 \mathrm{pg} / \mathrm{mL} ; 1,5 \pm 0,47 \mathrm{vs} 1,49 \pm 0,29 \mathrm{pg} / \mathrm{mL} ; 152,04 \pm 27,32$ vs $140,98 \pm 28,08 \mathrm{ng} / \mathrm{mL}$. Hanya kadar VEGF yang memiliki perbedaan yang bermakna $(289,76 \pm 188,13$ vs $581,29 \pm$ $512,85 \mathrm{pg} / \mathrm{mL}(\mathrm{p}<0,05))$. Perbedaan rerata VEGF memiliki nilai AUC 74,5\%. Titik potong optimal VEGF $\geq 314,75 \mathrm{pg} /$ $m L$ dengan sensitivitas $78,6 \%$ dan spesifisitas $69,2 \%$.
\end{abstract}

Kesimpulan: Penelitian ini menunjukkan penanda biologis serum VEGF (tetapi tidak IL-6, TNF- $\alpha$, dan MMP-2) dapat digunakan untuk mengukur derajat keparahan endometriosis. Kadar VEGF dari 314,75 pg/mL merupakan titik potong antara stadium yang lebih rendah dan lebih tinggi dari derajat keparahan. (Med J Indones. 2013;22:76-82)

\begin{abstract}
Background: The focus of this study was to compare serum biomarkers: interleukin-6 (IL-6), tumor necrosis factor-alpha (TNF- $\alpha$ ), matrix-metalloproteinase-2 (MMP-2) and vascular endothelial growth factor (VEGF) in endometriosis stage I-II and stage III-IV.

Methods: This is a cross-sectional study. Forty endometriosis patients were diagnosed using laparoscopy procedure. Serum sample was taken before the surgery. The serum biomarkers (IL-6, TNF- $\alpha$, MMP-2, and VEGF) were analyzed with ELISA method at the end of research. Mean of serum biomarkers in endometrosis stage I-II and stage III-IV were compared using unpaired t-test. Variables that show significant mean difference were tested using ROC measurement and the optimal cut-off point was determined.

Results: There was no significant difference in mean serum biomarkers level of IL-6, TNF- $\alpha$, and MMP-2 between endometriosis stage I-II and stage III-IV $(1.58 \pm 0.78 \mathrm{vs} 1.55 \pm 0.98 \mathrm{pg} / \mathrm{mL}, 1.5 \pm 0.47 \mathrm{vs} 1.49 \pm 0.29 \mathrm{pg} / \mathrm{mL}$, and 152.04 $\pm 27.32 \mathrm{vs} 140.98 \pm 28.08 \mathrm{ng} / \mathrm{mL}$, respectively). On the other hand, the comparison of VEGF level in endometriosis stage I-II and stage III-IV demonstrated significant difference $(289.76 \pm 188.13$ vs $581.29 \pm 512.85 \mathrm{pg} / \mathrm{mL}(\mathrm{p}<0.05))$. Mean difference of VEGF had AUC of $74.5 \%$. Optimal cut-off point for VEGF was $\geq 314.75 \mathrm{pg} / \mathrm{mL}$ with sensitivity $78.6 \%$ and specificity $69.2 \%$.

Conclusion: This study showed that serum biomarkers of VEGF level (but not IL-6, TNF- $\alpha$, and MMP-2) can be used to measure the degree of severity in endometriosis. VEGF level of $314.75 \mathrm{pg} / \mathrm{mL}$ represents the cut-off point between lower and higher stage of severity. (Med J Indones. 2013;22:76-82)
\end{abstract}

Keywords: Endometriosis, interleukin-6, matrix-metalloproteinase-2, TNF- $\alpha$, vascular endothelial growth factor

Endometriosis is a chronic inflammatory disease related to immune system which is characterized by ectopic endometrial tissue (stroma and gland). ${ }^{1-3}$ The most common symptoms are infertility and dysmenorrhea. ${ }^{1,2}$

Endometriosis is a common gynecologic disease in reproductive age which has affected $25-50 \%$ infertile women. ${ }^{4}$ There is an increase in incidence of endometriosis in Indonesia as noted from one study in Soetomo Hospital, Surabaya, which show the incidence of endometriosis of $23 \%$ in $1980,37 \%$ in 1990 and it reached 50\% in 2002. ${ }^{5}$ Data from Cipto Mangunkusumo Hospital shows that the incidence has reached $69.5 \%$ in infertile women. ${ }^{6}$ The concurrence of endometriosis and infertility event has increased in urban city compared to rural area. It is assumed that the difference of lifestyle between both area could contribute to this outcome. Infertile women with endometriosis come from higher social economic class who usually postpone having a child because of work. ${ }^{6,7}$ 
Based on guidelines of European Society of Human Reproduction and Embryology in 2005, practice guidelines of American College of Obstetricians and Gynecologists in 2000 and committee opinion of American College of Obstetricians and Gynecologists in 2005, it is stated that the diagnosis of endometriosis can be determined by visualization of the lesion in laparoscopy. ${ }^{8}$ In undetermined cases, biopsy with histologic confirmation is recommended, but positive histologic findings were not needed to diagnose all cases. The surgeon is responsible to find endometriosis lesion with his judgement during operation. ${ }^{2,8,9}$ Recently, it has been accepted that the gold standard for diagnosis of endometriosis is by lesion visualization with laparoscopy. ${ }^{2,9}$

Classification of severity of endometriosis was done by examining lesion location at pelvic cavity. The American Society for Reproduction Medicine (ASRM) in 1996 divided endometriosis into 4 stages: minimal (I), mild (II), moderate (III), and severe (IV). ${ }^{2}$ This classification is often narrowed into stage I-II and stage III-IV to reduce the subjectivity for classifying the severity. ${ }^{10}$

Changes in body immune system have important role in development of endometriosis. Local immuneinflammation in peritoneal cavity will activate immune cells, together with endometriosis implantation will produce cytokines, growth factors, and angiogenic molecules in high level. ${ }^{1,3,4,9,11}$ Systemic immune changes also occur in endometriosis, including increase of peripheral blood monocytes. ${ }^{12,13}$ These cells produce higher cytokines than peripheral monocytes in basal condition of healthy women. In endometriosis patients, these cytokines will attract and recruit more immune cells, promote implantation and growth of ectopic endometrium by inducing proliferation and angiogenesis on the surface of peritoneum, and help invasion of cells to the mesothelium. ${ }^{3,12,14}$

After infiltration of endometriosis cells, angiogenic process takes important role to sustain the implant and promote growth of endometriosis. VEGF has important role in the regulation of normal angiogenesis and pathogenic neovascularization. ${ }^{3,4,15}$ VEGF level in peritoneal fluid was higher in endometriosis patients compared to control. ${ }^{16}$ However, some studies reported controversial results. ${ }^{16,17}$

The changes in cells and cytokines within peritoneal fluid is undoubtedly due to endometriosis induced local inflammation. However, it is not clear yet that local immunologic inflammation can affect the peripheral cytokines, and whether the changes are significant enough to be used as non-invasive diagnostic tools for endometriosis need further studies.

Many cytokines have been studied in relation with endometriosis, either from peritoneal cavity or from serum. Among them, IL-6 has shown robust result of increment in the peritoneal fluid and serum of endometriosis women. ${ }^{2,12,18-20}$ TNF- $\alpha$ and MMP-2 levels also increase in endometriosis women. ${ }^{12,15,20-22}$ The purpose of this study is to evaluate whether severity of endometriosis is related to differences in serum biologic markers level.

\section{METHODS}

This cross-sectional study was performed from January-April 2012 at Raden Saleh Reproductive Health Clinics Dr. Cipto Mangunkusumo Hospital, Bunda Hospital, and YPK Maternal and Children Hospital in Jakarta. The inclusion criteria were women at reproductive age (18-42 year old) who had the complains related to endometriosis (infertility, dysmenorrhea, chronic pelvic pain, cervical tenderness, and rectovaginal nodule) with no history of pelvic inflammatory disease, cancer or autoimmune disease and had given informed consent to join the study. Meanwhile, those under hormonal treatment at least in last three months, leukocyte level $>12,000 /$ $\mu \mathrm{L}$, erythrocyte sedimentation rate (ESR) $>30 \mathrm{~mm} /$ hour, and/or quantitative C-reactive protein (CRP) level $>10 \mathrm{mg} / \mathrm{L}$ were excluded. The protocol of the study has been approved by Ethics Committee of Faculty of Medicine Universitas Indonesia with the letter number 46/PT02.FK/Etik/2012.

We use $\alpha 5 \%$ and $\beta 20 \%$ to calculate minimal sample requirement for mean difference of two unpaired group. The minimal sample requirement was 38 subjects. Anamnesis, general physical examination including gynecologic examination and some laboratory tests were performed. Laparoscopy was used as gold standard to diagnose endometriosis. Endometriosis was classified in accordance with ASRM classification for endometriosis.

Education level of the subjects was recorded. The patient is classified as having high education if she graduated with bachelor degree, moderate education if she had high school degree, and low education if she only finished junior high school degree or lower.

Forty endometriosis patients were diagnosed with endometriosis based on laparoscopic procedure. A $10 \mathrm{~mL}$ blood samples was taken before anesthesia during surgery, centrifuged, and the serum were 
directly stored at Prodia Kramat laboratory at $-20^{\circ} \mathrm{C}$. The serum biomarkers (IL-6, TNF- $\alpha$, MMP-2, and VEGF) were analyzed in duplo with enzyme-linked immuno sorbent assay (ELISA) method. The reagents used were from R\&D products except for MMP2 which was Biovendor product. Means of serum biomarkers in endometrosis stage I-II and stage IIIIV were compared using unpaired t-test. P-value of $<0.05$ were considered significant. Variables that show significant mean difference were tested using ROC measurement and the optimal cut-off point was determined.

\section{RESULTS}

Forty patients with endometriosis were included in this study. Twenty six were classified as endometriosis stage I-II and the remaining were classified as stage IIIIV. Table 1 shows the characteristic of study subjects.

\section{Biologic markers}

The results of statistical analysis of biologic markers are shown in table 2 . There was no statistically significant difference of IL-6, TNF- $\alpha$, and MMP-2 serum levels between stage I-II and III-IV. On the other hand, the comparison of mean VEGF serum level in stage I-II and stage III-IVdemonstrates significant difference $(289.76 \pm 188.13$ vs $581.29 \pm 512.85 \mathrm{pg} / \mathrm{mL} ; \mathrm{p}<0.05)$.

Mean differences for biologic markers TNF- $\alpha$ and MMP2 were shown in arithmetic difference $(\Delta x)$ because they have normal distribution. Meanwhile, IL-6 and VEGF data had to be subjected to logarithmic transformation because they are not normally distributed therefore the mean differences were shown in geometric ratio. Area under curve (AUC) of receiver operating characteristic
$(\mathrm{ROC}) \leq 0.5$ has weak diagnostic value to differentiate stage I-II and stage III-IV.

\section{Cut-off point for serum VEGF level}

In bivariate analysis, only serum VEGF level had significant difference for endometriosis stage I-II vs stage III-IV. From ROC analysis, it is found that AUC of ROC $74.5 \%(p<0.05)$ could be considered to have good diagnostic value (Figure 1). It is shown in table 3 several cut-off point for serum VEGF level to differentiate stage I-II and stage III-IV. Figure 2 demonstrates the optimal cut-off point in between

Table 1. Subject characteristics

\begin{tabular}{lcc}
\hline \multicolumn{1}{c}{ Variable } & $\begin{array}{c}\text { Stage I-II } \\
\mathrm{n}=26(65 \%)\end{array}$ & $\begin{array}{c}\text { Stage III-IV } \\
\mathrm{n}=14(35 \%)\end{array}$ \\
\hline Age (years) mean \pm SD & $34.1 \pm 9.3$ & $30.3 \pm 7.6$ \\
Education level & & \\
High & $22(84.62 \%)$ & $13(92.86 \%)$ \\
Moderate & $2(7.69 \%)$ & $1(7.14 \%)$ \\
Low & $2(7.69 \%)$ & $0(0 \%)$ \\
BMI & & \\
Low (<18.5) & $0(0 \%)$ & $0(0 \%)$ \\
Normal $(18.5-24.9)$ & $24(92.31 \%)$ & $11(78.57 \%)$ \\
Obese (BMI $\geq 25)$ & $2(7.69 \%)$ & $3(21.43 \%)$ \\
Smoking & $2(7.69 \%)$ & $2(14.29 \%)$ \\
Infertility & & \\
Primary & $22(84.62 \%)$ & $8(57.14 \%)$ \\
Secondary & $1(3.85 \%)$ & $0(0 \%)$ \\
Parity & & $12(85,72 \%)$ \\
0 & $23(88.46 \%)$ & $1(7.14 \%)$ \\
1 & $2(7.69 \%)$ & $14 \%)$ \\
2 & $1(3.85 \%)$ & \\
Total & $0(0 \%)$ & \\
\hline
\end{tabular}

Table 2. Statistical analysis of serum biologic markers of endometriosis patients

\begin{tabular}{lccccc}
\hline Variable & Mean \pm SD & CI 95\% & p & $\begin{array}{c}\text { AUC } \\
\text { of ROC }\end{array}$ & $\begin{array}{c}\text { p from } \\
\text { AUC }\end{array}$ \\
\hline IL-6 (pg/mL) & & & & & \\
Std I-II & $1.58 \pm 0.78$ & & & & \\
Std III-IV & $1.55 \pm 0.98$ & $-0.53-0.58$ & 0.640 & 0.453 & 0.63 \\
TNF- $\alpha(\mathrm{pg} / \mathrm{mL})$ & & & & & \\
Std I-II & $1.50 \pm 0.47$ & & & & \\
Std III-IV & $1.49 \pm 0.29$ & $-0.27-0.29$ & 0.078 & 0.499 & 0.989 \\
MMP-2 (ng/mL) & & & & & \\
Std I-II & $152.04 \pm 27.32$ & & & & \\
Std III-IV & $140.98 \pm 28.08$ & $-7.44-29.57$ & 0.857 & 0.402 & 0.314 \\
VEGF (pg/mL) & & & & & \\
Std I-II & $289.76 \pm 188.13$ & & & & \\
Std III-IV & $581.29 \pm 512.85$ & $-517.38-65.68$ & 0.011 & 0.745 & 0.012 \\
\hline
\end{tabular}



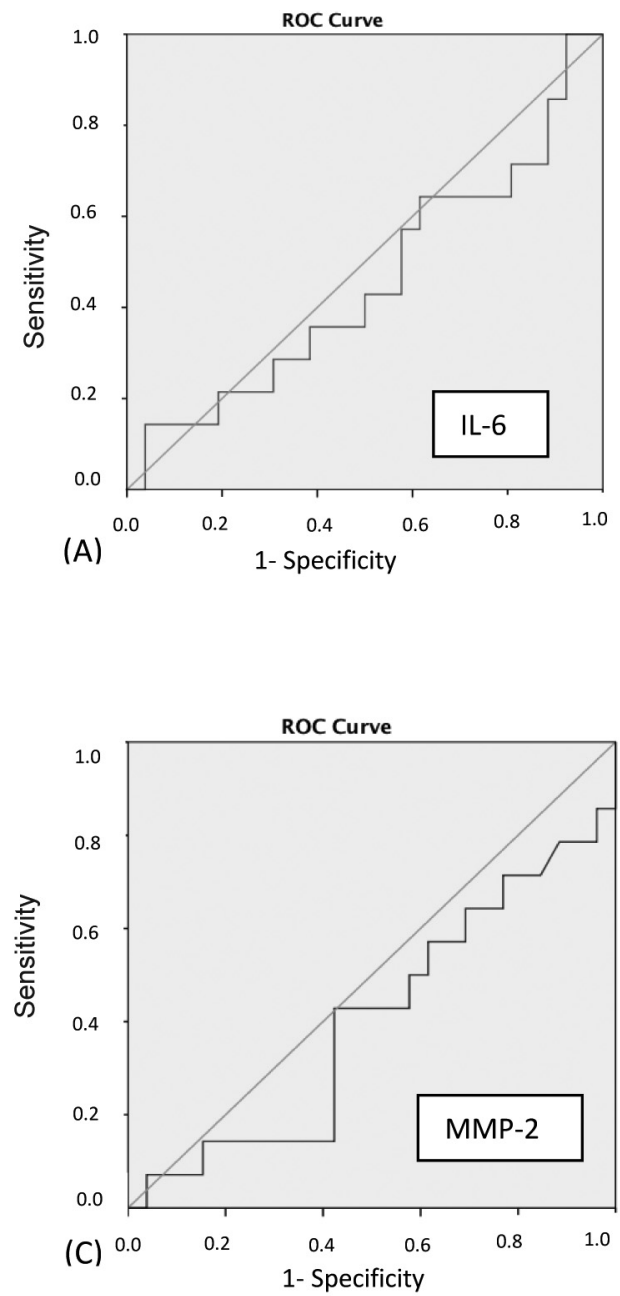
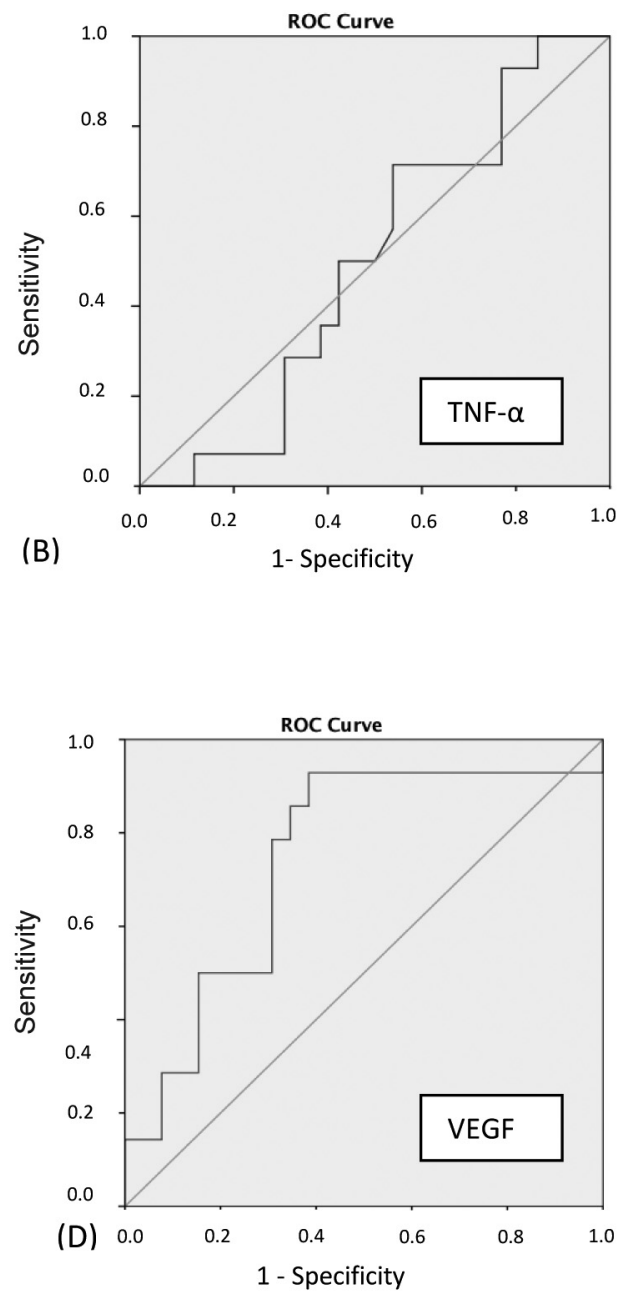

Figure 1. ROC graphics of serum biologic marker level. (A) IL-6,(B) TNF- $\alpha$, (C) MMP-2, and (D) VEGF. Only VEGF has AUC more than diagonal line.

sensitivity and specificity. The optimal value for serum VEGF level to differentiate stage I-II and stage III-IV is $314.75 \mathrm{pg} / \mathrm{mL}$ with sensitivity $78.6 \%$ and specificity $69.2 \%$.

\section{DISCUSSION}

Endometriosis is a subclinical chronic inflammation related to immune system. ${ }^{3,4,12,19}$ There has been several previous researchers who analyzed biologic marker level in endometriosis patients by comparing its increment to normal population. Biologic marker level can also be used to determine the progression of endometriosis. Based on Sampson's theory of menstrual regurgitation, $10 \%$ women who had menstrual regurgitation will have endometrial cells which adhere to peritoneal wall. This adherence will in turn activate macrophage to trigger inflammatory response. ${ }^{1-4}$

This study was meant to see the progression of inflammatory response in advanced stage (moderate-
Table 3. Several cut-off point for serum VEGF for differentiating sensitivity and specificity

\begin{tabular}{llll}
\hline No & $\begin{array}{l}\text { Cut-off point } \\
\text { VEGF }(\mathrm{pg} / \mathrm{mL})\end{array}$ & Sensitivity & Specificity \\
\hline 1 & 56.20 & 1 & 0 \\
2 & 66.65 & 0.929 & 0 \\
$\ldots \ldots$ & & & \\
18 & 285.60 & 0.929 & 0.615 \\
19 & 289.95 & 0.857 & 0.615 \\
20 & 295.85 & 0.857 & 0.654 \\
21 & 305.00 & 0.786 & 0.654 \\
22 & 314.75 & 0.786 & 0.692 \\
23 & 323.95 & 0.714 & 0.692 \\
24 & 346.80 & 0.643 & 0.692 \\
25 & 368.05 & 0.500 & 0.692 \\
26 & 372.95 & 0.500 & 0.731 \\
$\ldots \ldots$. & & & \\
40 & 2009.2 & 0 & 1 \\
\hline
\end{tabular}

severe) of endometriosis in comparison with early (minimal-mild) stage. The results of this study show that there were no difference in IL- 6 , TNF- $\alpha$, and 


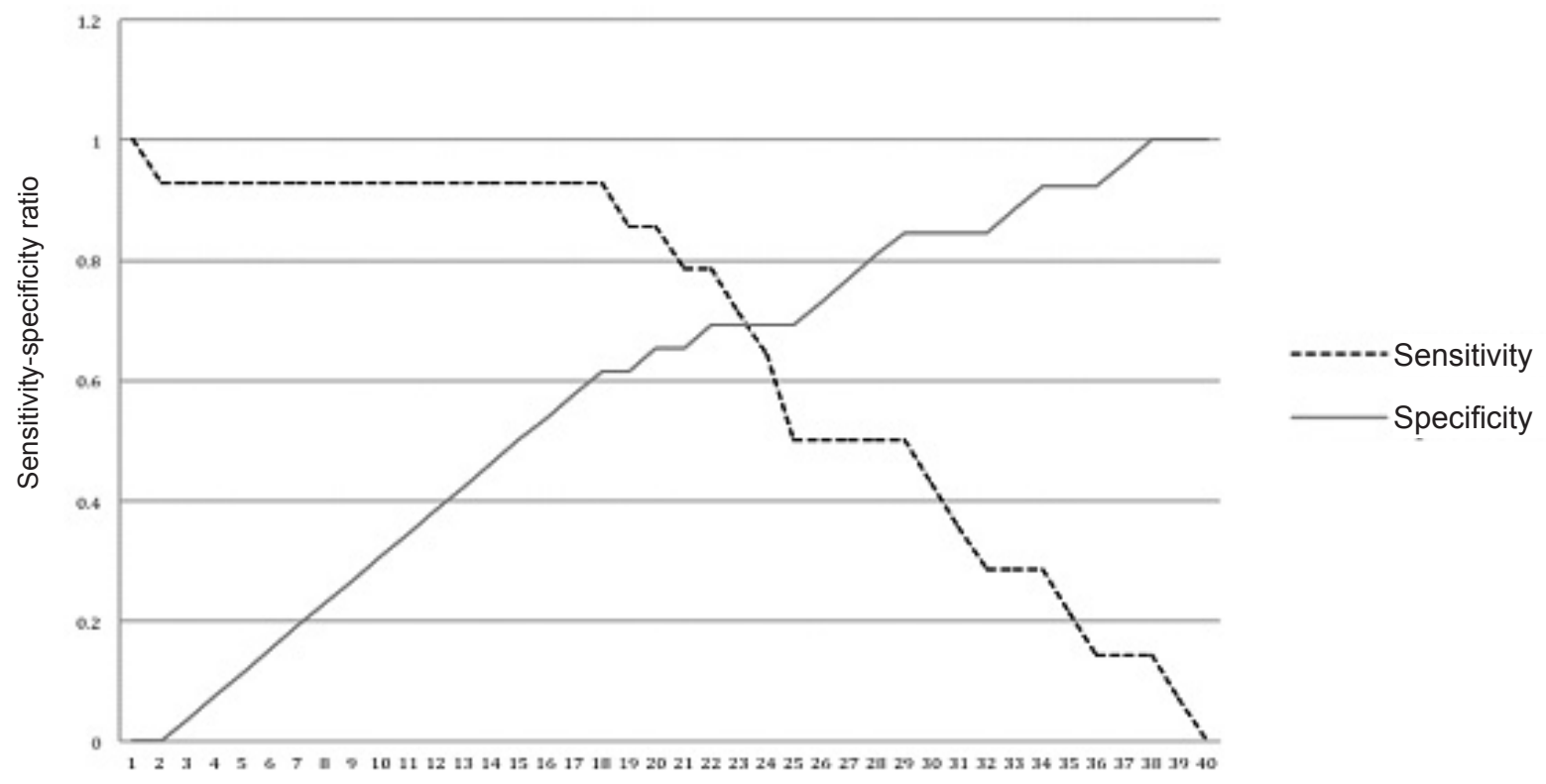

Figure 2. Sensitivity and specificity curve of serum VEGF

MMP-2 serum level between stage I-II and stage IIIIV. These biologic markers do not have diagnostic value to differentiate both conditions. The AUC-ROC of each serum biologic marker value, were $<50 \%$ with $\mathrm{p}$-value $>0.05$. This means their usage will have $50 \%$ of probability to differentiate both conditions.

IL-6 is a main indicator of acute inflammatory response. IL-6 has several biologic activities, including acute phase protein on hepatocyte, lymphocyte-B growth and differentiation, and lymphocyte-T activation. In fact, IL- 6 and TNF- $\alpha$ are also secreted by peritoneal macrophage and ectopic endometriosis tissue.

The increase of peritoneal IL- 6 and TNF- $\alpha$ level in patients with endometriosis has already been proven by many researchers. Maas ${ }^{23}$ performed in vitro study to examine angiogenesis process by injecting peritoneal fluid of endometriotic women to chicken chorioalantoic membrane. The peritoneal fluid was measured for cytokines of TNF- $\alpha$, IL- $1 b$, and IL- $8 .{ }^{23}$ Only TNF- $\alpha$ showed significant positive correlation. Peritoneal fluid of IL-6 and TNF- $\alpha$ also reported to increase proliferation from eutopic and ectopic endometrial tissue. $^{23}$

MMP-2 system is assumed to have association with pathogenesis of endometriosis during implantation process. Matrix degradation is needed to ensure invasion of endometriosis implant. From in vitro experimental study, there was increment of MMP-2 expression from endometriosis cells of endometriosis women transplant. ${ }^{15}$ There is only one study that compares the level of serum MMP-2 in endometriosis patients to control. Research performed by Huang ${ }^{22}$ had shown that there were increase in peritoneal fluid and serum of MMP-2 in endometriosis patients. However, our study demonstrates different result from Huang by showing increment of MMP-2 in different stage of endometriosis.

Mihalyi ${ }^{19}$ performed a study to analyze six serum biologic markers (IL-6, IL-8, TNF- $\alpha$, hs-CRP, CA-125, and CA-19-9) in attempt to find the difference in these biologic markers level between endometriosis patients and control. It was found that only three serum biologic markers level (IL-6, IL-8 and CA-125) that increase in endometriosis patients compared to control. ${ }^{19}$ Serum IL-6 level had diagnostic value with AUC 70.5\%, sensitivity $59 \%$ and specificity $76.3 \%$ on optimal cut-off point.

Martinez $^{24}$ and Othman ${ }^{25}$ reported mean serum IL-6 in endometriosis women stage I-II ( 28.4 and $5.39 \mathrm{pg} / \mathrm{mL})$ was higher than stage III-IV (17.5 and $3.45 \mathrm{pg} / \mathrm{mL}$ ). Only study conducted by Othman ${ }^{25}$ reported analytic statistical test to find the mean difference between both endometriosis stages, which showed no significant difference between both conditions.

May had done systematic review of serum biologic markers in endometriosis patients compared to control. Studies that examined serum IL- 6 and TNF- $\alpha$ still give conflicting result. ${ }^{12}$ Chae who conducted the study in Korea also reported no difference in serum TNF- $\alpha$ level of endometriosis women compared to control. $^{26}$ 
In pathogenesis of endometriosis, angiogenesis has important role. Angiogenesis is a complex process, including local degradation of basal membrane of native blood vessels and it is followed by migration and proliferation of endothelial cells. Angiogenesis is influenced by angiogenic factors, one of which is VEGF. ${ }^{20}$ Stimulation of blood vessel growth by VEGF is already proven by in vitro and in vivo studies. McLaren reported that peritoneal fluid VEGF level in endometriosis women was higher than control. ${ }^{27}$ Inflammation and neovascularization are also found in adjacent of ectopic endometrial tissue implant. Inflammatory leukocytes are found in this lesion and also in the peritoneal fluid. Donnez had succeeded to show mRNA VEGF and expression of the protein in the endometriosis tissue. ${ }^{20}$ Study conducted by Cosin showed that peritoneal fluid influences VEGF secretion from neutrophils and ectopic endometrial tissue. ${ }^{28}$ Meanwhile, Estelles had proven positive correlation of peritoneal fluid VEGF with fibrinolysis and metalloproteinase system with increment of urokinase plasminogen and MMP-3. ${ }^{29}$

The comparison of serum VEGF level in endometriosis and control was already examined by previous studies. In the systematic review done by May, ${ }^{12}$ at least four studies had already been conducted, all of which did not find any increment of serum VEGF level compared to control. Only two studies showed the increment of VEGF level. Even though there was no study that differentiated endometriosis stage related to serum VEGF level. ${ }^{12}$

This study shows that there is significant difference of serum VEGF level in stage I-II and stage III-IV. Mean serum level of VEGF is $238.78 \mathrm{pg} / \mathrm{mL}$ in minimal-mild and $426.57 \mathrm{pg} / \mathrm{mL}$ in moderate-severe endometriosis. The difference ratio of mean is 1.81 . Mean ratio was used rather than arithmetic ratio due to logarithmic transformation of data in the analysis. This difference has AUC of $74.5 \%$. The cut-off point serum VEGF level is 314.75 with sensitivity $78.6 \%$ and specificity $69.2 \%$.

Manero $^{30}$ found no difference of serum VEGF level in endometriosis patients who had no symptoms or minimal-mild dysmenorrhea compared to severe dysmenorrhea. Even though increment of serum VEGF had positive correlation with C-reactive protein. ${ }^{30}$ Study conducted by Nogueira found peritoneal fluid VEGF level difference in endometriosis patients who had dyspareunia compared to patients who did not have the symptoms. ${ }^{31}$

The weakness of this study is that we did not consider the hormonal cycle of patient in the analysis. Estrogen could affect the increment of serum MMP-2. Huang had shown positive correlation of serum 17b-E2 with serum MMP-2 level. ${ }^{22}$ Even though Othman showed that there was no difference in serum IL- 6 and TNF- $\alpha$ level during proliferation phase and secretion phase of menstrual cycle. ${ }^{25}$ Our study also has limitation of internal validity of stress factor affecting the subjects before the surgery which could cause the increase of inflammatory factors.

In conclusion, this study shows that serum biomarkers of IL-6, TNF- $\alpha$, and MMP-2 cannot be used to differentiate endometriosis stage I-II and stage IIIIV. In contrast, VEGF level may be used to measure the degree of severity in endometriosis since higher VEGF level present in later stage of endometriosis. This result is in accordance with the pathophysiology of endometriosis.

\section{Acknowledgment}

We would like to thank dr. M Sopiyudin Dahlan, M.Epid as statistic consultant who wrote series of statistic books that used as statistic guidance analysis of this study.

\section{REFERENCES}

1. Jacoeb TZ. Faktor Imunoendokrinologis dan seluler lingkungan mikro zalir peritoneal yang berperan pada infertilitas idiopatik wanita [dissertation]. Mount Pleasant (MI): Universitas Indonesia; 1990. Indonesian.

2. Jacoeb TZ, Hadisaputra W. Penanganan endometriosis: panduan klinis dan algoritme. 1 ed. Jakarta: CV Sagung Seto; 2009. Indonesian.

3. Lebovic DI, Muller MD, Taylor RN. Immunobiology of endometriosis. Fertil Steril 2001;75(1):1-10.

4. Harada T, Iwabe T, Terakawa N. Role of cytokines in endometriosis. Fertil Steril 2001;76(1):1-10.

5. Hendarto H. Profil kadar TNF- $\alpha$, GDF-9 dan hyaluronan pada gangguan folikulogenesis sebagai gambaran penurunan kualitas oosit pasien endometriosis yang infertil [dissertation]. Mount Pleasant (MI): Universitas Airlangga; 2007. Indonesian.

6. Oepomo TD. Peran interleukin-6 serta interleukin-8 dalam zalir peritoneal penderita infertilitas disertai endometriosis dalam proses apoptosis sel granulosa avarii yang patologis [dissertation]. Mount Pleasant (MI): Universitas Airlangga; 2003. Indonesian.

7. Adiyono W. Dampak penambahan gonadotropin releasing hormon analog pada operasi laparoskopi terhadap manifestasi klinis, imunologis dan kualitas hidup penderita endometriosis [dissertation]. Mount Pleasant (MI); 2003. Indonesian.

8. Stegmann BJ, Funk MJ, Sinaii N, et al. A logistic model for the prediction of endometriosis. Fertil Steril 2009;91(1):51-5.

9. Hadisaputra W. Endometriosis: tinjauan perangai imunopatobiologi sebagai modalitas baru untuk menegakkan diagnosis endometriosis tanpa 
visualisasi Laparoskopi. Maj Obstet Ginekol Indones. 2007;31(3):180-4. Indonesian.

10. ASRM PC. Endometriosis and infertility. Fertil Steril 2004;81(5):1441-6.

11. Vignali M, Infantino M, Matrone R, et al. Endometriosis: novel etiopathogenetic concepts and clinical prespectives. Fertil Steril 2002;78(4):665-78.

12. May K, Conduit-Hulbert S, Villar J, Kirtley S, Kennedy S, Becker C. Peripheral biomarkers of endometriosis: a systematic review. Hum Reprod Update. 2010;16(6):651-74.

13. Gagne D, Rivard M, Page M, Shazand K, Hugo P, Gosselin D. Blood leukocyte subsets are modulated in patients with endometriosis. Fertil Steril 2003;80(1):43-53.

14. Gupta S, Goldberg JM, Aziz N, Goldberg E, Krajcir N, Agarwal A. Pathogenic mechanisms in endometriosisassociated infertility. Fertil Steril 2008;90(2):247-57.

15. Pitsos M, Kanakas N. The role of matrix metalloproteinases in the pathogenesis of endometriosis. Reprod Sci. 2009;16(8):717-26.

16. Donnez J, Smoes P, Gillerot S, Casanas-Roux F, Nisolle M. Vascular endothelial growth factor (VEGF) in endometriosis. Hum Reprod. 1998;13(6):1686-90.

17. Laschke MW, Menger MD. In vitro and in vivo approaches to study angiogenesis in the pathophysiology and therapy of endometriosis. Hum Reprod Update. 2007;13(4):331-42.

18. Witz CA. Interleukin-6: another piece of the endometriosiscytokine puzzle. Fertil Steril 2000;73(2):212-4.

19. Mihalyi A, Gevaert O, Kyama C, et al. Non-invasive diagnosis of endometriosis based on a combined analysis of six plasma biomarkers. Hum Reprod. 2010;25(3):654-64.

20. Matalliotakis I, Goumenou A, Koumantakis G, et al. Serum concentration of growth factors in women with and without endometriosis: the action of anti-endometriosis medicines. Int Immunopharmacol. 2003;3(1):81-9.

21. Xavier P, Belo L, Beires J, et al. Serum levels of VEGF and $\mathrm{TNF}$-alpha and their association with $\mathrm{C}$-reactive protein in patients with endometriosis. Arch Gynecol Obstet. 2006;273(4):227-31.
22. Huang H-F, Hong L-H, Tan Y, Sheng J-Z. Matrix metalloproteinase 2 is associated with changes in steroid hormones in the sera and peritoneal fluid of patients with endometriosis. Fertil Steril 2004;81(5):1235-9.

23. Maas JW, Groothuis PG, Dunselman GA, de Goeij AF, Struijker-Boudier HA, Evers JL. Development of endometriosis-like lesions after transplantation of human endometrial fragments onto the chick embryo chorioallantoic membrane. Hum Reprod. 2001;16(4):627-31.

24. Martinez S, Garrido N, Coperias J, et al. Serum interleukin-6 levels are elevated in women with minimal mild endometriosis. Hum Reprod. 2007;22(3):836-42.

25. Othman EE-DR, Hornung D, Hosam, et al. Serum cytokines as biomarker for nonsurgical prediction of endometriosis. Eur J Obstet Gynecol. 2007;137:240-6.

26. Chae SJ, Kim H, Jee BC, Suh CS, Kim SH, Kim JG. Tumor necrosis factor (TNF)-TNF receptor gene polymorphisms and their serum levels in Korean women with endometriosis. Am J Reprod Immunol. 2008;60(5):432-9.

27. McLaren J. Vascular endothelial growth factor and endometriotic angiogenesis. Hum Reprod Update. 2000;6:45-55.

28. Cosin R, Estelles JG, Ramon L, et al. Influence of peritoneal fluid on the expression of angiogenic and proteolytic factors in cultures of endometrial cells from women with endometriosis. Hum Reprod. 2010;25(2):398-405.

29. Gilabert-Estelles J, Ramon LA, Espana F, et al. Expression of angiogenic factors in endometriosis: relationship to fibrinolytic and metalloproteinase systems. Hum Reprod. 2007;22(8):2120-7.

30. Garcia-Manero M, Santana GT, Alcazar JL. Relationship between microvascular density and expression of vascular endothelial growth factor in patients with ovarian endometriosis. J Womens Health (Larchmt). 2008;17(5):777-82.

31. Pupo-Nogueira A, de Oliveira RM, Petta CA, Podgaec S, Dias JA, Jr., Abrao MS. Vascular endothelial growth factor concentrations in the serum and peritoneal fluid of women with endometriosis. Int J Gynaecol Obstet. 2007;99(1):33-7. 